\title{
IDENTIFIKASI SPESIES MENGGUNAKAN DNA BARCODING DALAM MENUNJANG BUDIDAYA DAN KONSERVASI TERIPANG DI PERAIRAN LAMPUNG
}

\author{
Anna Rejeki Simbolon* ${ }^{* *}$, Masteria Yunovilsa Putra**, dan Ismiliana Wirawati*) \\ *) Pusat Penelitian Oseanografi, Lembaga IImu Pengetahuan Indonesia (LIPI) \\ J.. Pasir Putih I, Ancol Timur, Jakarta 14430 \\ * Pusat Penelitian Bioteknologi LIPI \\ Komplek CSC-LIPI JIn. Raya Bogor Km 46, Cibinong 16911, Bogor
}

(Naskah diterima: 25 September 2020; Revisi final: 8 Februari 2021; Disetujui publikasi: 8 Februari 2021)

\begin{abstract}
ABSTRAK
Teripang merupakan komoditas perikanan yang saat ini dibudidayakan dan dieksploitasi di perairan Lampung. Namun terdapat kesulitan dalam mengidentifikasi teripang karena kemiripan morfologis di antara spesies yang ada. Identifikasi yang baik berguna agar proses pembudidayaan dan konservasi dapat tepat sasaran. Penggunaan DNA barcoding dapat digunakan untuk mengidentifikasi jenis-jenis teripang yang ada, jarak genetik, dan keragaman genetik intra/inter spesies. Penelitian ini bertujuan untuk mengidentifikasi teripang di perairan Lampung dengan menggunakan sekuen DNA gen COI. Teripang diambil dengan menggunakan metode jelajah pada saat surut dan dengan scuba diving. Pengamatan DNA menggunakan primer universal ceF, pengeditan dan diurutkan dengan program Geneious ver 9 dan program BLAST. Konstruksi pohon filogenetik dilakukan dengan metode neighbor joining (NJ) pada model Kimura-2. Penelitian ini menunjukkan spesies teripang yang teridentifikasi adalah Holothuria leucospilota, $\mathrm{H}$. atra, Stichopus vastus, dan S. horrens dengan jarak kesamaan $99 \% 100 \%$ S. vastus dan S. horrens memiliki jarak genetik terendah dengan pengurangan yang tinggi. Rekonstruksi filogenetik memperlihatkan pengelompokkan spesies-spesies ke dalam genus Holothuria dan Stichopus. Stichopus sp. memiliki kesamaan morfologi yang tinggi sehingga kesalahan identifikasi sering terjadi. DNA barcoding dapat mengidentifikasi teripang secara cepat dan akurat sehingga pengelolaan teripang baik secara budidaya maupun pengambilan langsung di alam dapat berkelanjutan. Identifikasi spesies yang tepat menjadi kunci utama dalam upaya pembudidayaan dan konservasi teripang yang tepat sasaran dan berkelanjutan.
\end{abstract}

\section{KATA KUNCl: $\quad$ barcoding; DNA; COI; teripang}

ABSTRACT: Species identification using DNA barcoding in supporting the cultivation and conservation of sea cucumber in Lampung waters. By: Anna Rejeki Simbolon, Masteria Yunovilsa Putra, and Ismiliana Wirawati.

Sea cucumbers is a highly valued fishery commodity that is currently cultivated and exploited in Lampung waters. However, differentiating a sea cucumber species from another is sometimes difficult due the morphological similarities between the species. Developing an accurate identification method is then critical to ensure successfull farming activities and conservation efforts of sea cucumbers. DNA barcoding could be used to accurately identify sea cucumber species, genetic distance, and genetic diversity between species. This study aimed to identify sea cucumbers existed in Lampung waters using DNA barcoding of the $\mathrm{CO}$ gene with ceF and ceR universal primers. Sea cucumbers are taken using the cruising method at low tide and by scuba diving. The DNA sequence was then edited and aligmented using the Geneious ver.9 program and analyzed using the BLAST program. Phylogenetic tree construction was carried out using the neighbor joining (NJ) method on the Kimura-2 model. This study showed that the identified species of sea cucumbers were Holothuria leucospilota, H. atra, Stichopus vastus, and S. horrens with a similarity distance of $99 \% 100 \%$ S. vastus and S. horrens have the lowest genetic range. Phylogenetic reconstruction

\footnotetext{
\# Korespondensi: Pusat Penelitian Oseanografi, Lembaga IImu Pengetahuan Indonesia (LIPI). JI. Pasir Putih I, Ancol Timur, Jakarta 14430, Indonesia 
shows the classification of species into the genus Holothuria and Stichopus. Stichopus sp. have high morphological similarities within the same genus which often lead to species misidentification. DNA barcoding can identify sea cucumbers quickly and accurately. This method allows the identification of the right sea cucumber species which is the main key in the effort to cultivate and conserve targeted and sustainable sea cucumbers.

\section{KEYWORDS: barcoding; DNA; COI; sea cucumbers}

\section{PENDAHULUAN}

Holothuroidea merupakan salah satu jenis teripang atau timun laut bernilai ekonomis tinggi dan memiliki pasar yang baik. Teripang sering dijumpai dan terdistribusi secara luas di wilayah Indo Pasifik. Studi di bidang farmakologi menunjukkan bahwa ekstrak teripang mengandung metabolit dan senyawa bioaktif potensial yang dapat digunakan dalam industri farmasi. Kandungan bahan aktif teripang yang dipercaya dapat meningkatkan stamina tubuh dan bahan baku obat.

Sebelum tahun 2000 Indonesia adalah negara eksportir teripang terbesar di dunia dengan tujuan ekspor utama adalah Hongkong. Namun akibat eksploitasi yang berlebihan oleh nelayan semakin sulit mendapatkan teripang dengan jenis-jenis tertentu. Dalam lima tahun terakhir, International Unionfor Conservation of Nature (IUCN) mengevaluasi lebih dari 300 jenis timun laut Ordo Aspidochirotida dalam rangka mengetahui status populasinya. Sementara itu, Convention on Interantional Trade in Endangered Species of Wild Fauna and Flora (CITES) bersama-sama dengan negara-negara eksportir teripang mendiskusikan mengenai perlunya memasukkan teripang ke dalam daftar Appendix II atau Appendix III CITES. CITES (2020) menyatakan jenis teripang yang telah masuk ke dalam daftar apendiks II yaitu dari jenis teripang susu (Holothuria fuscogilva, H. nobilis, dan $\mathrm{H}$. whitmaei).

Perairan Lampung merupakan salah satu wilayah di Indonesia yang melakukan budidaya teripang. Jenis teripang yang dibudidaya umumnya Holothuria scabra. Identifikasi teripang umumnya dilakukan secara morfologi, namun metode ini memiliki keterbatasan dikarenakan adanya beberapa spesies yang memiliki kemiripan morfologi yang tinggi, padahal identifikasi spesies yang tepat berguna agar proses pembudidayaan maupun konservasi spesies dapat tepat sasaran. Selain itu, teripang merupakan biota laut yang sangat mudah mengalami kontraksi sehingga seluruh karakter morfologinya masuk ke dalam tubuh. Teripang juga mampu melakukan eviserasi atau mengeluarkan organ internal sampai memutuskan diri menjadi beberapa bagian saat mengalami stres dan bertahan hidup (Wirawati et al., 2019). Oleh karena itu, diperlukan metode untuk mengidentifikasi teripang secara molekular. Salah satu metode yang dapat digunakan untuk mengidentifikasi spesies dan keragaman genetiknya ialah DNA barcoding. Metode DNA barcoding pertama kali diterapkan pada tahun 2003 (Hebert et al., 2003). Metode ini juga dapat digunakan untuk memvalidasi spesies kriptik yang banyak ditemukan pada hewan dengan morfologi yang serupa namun terdapat perbedaan genetis (Trivedi et al., 2016). DNA barcoding dapat digunakan untuk mengidentifikasi spesies baik dalam stadium telur, larva, dan dewasa (Briski et al., 2011). Sehingga metode ini menjadi sangat popular baik bagi para taksonom modern maupun para ahli ekologi dalam memprediksi sejarah hidup suatu spesies (Trivedi et al., 2016).

Secara umum, DNA barcoding adalah pendekatan standar untuk mengidentifikasi tumbuhan dan hewan dengan urutan minimal sekuen DNA. Sementara itu, barcode DNA ialah sebuah urutan DNA pendek, dari sebuah wilayah yang seragam pada genom, yang digunakan untuk mengidentifikasi spesies (Zein \& Prawiradilaga, 2013). Identifikasi spesies teripang baik secara morfologi dan genetik di perairan Indonesia masih belum banyak dilakukan. Penelitian mengenai teripang di Indonesia selama ini hanya sebatas distribusi dan morfologi. Saat ini, diketahui terdapat 45 spesies teripang yang ada di perairan seluruh Indonesia, dengan 22 spesies termasuk genus Holothuria (Setyastuti et al., 2019). Penggunaan DNA barcoding telah dilakukan oleh Madduppa et al. (2017) untuk mengidentifikasi jenis-jenis teripang yang tersebar di Kepulauan Seribu.

Penelitian DNA barcoding terkait jenis teripang yang dieksploitasi maupun tujuan pembudidayaan di perairan Lampung belum pernah dilakukan sehingga perlu dilakukan identifikasi jenis teripang agar pemanfaatan dan pelestarian spesies dapat dilakukan dengan baik. Penelitian ini bertujuan untuk mengidentifikasi spesies teripang yang di perairan Lampung dengan menggunakan DNA barcoding.

\section{BAHAN DAN METODE}

\section{Teknik Pengambilan Sampel}

Lokasi pengambilan sampel teripang di perairan Lampung ( $\left.5^{\circ} 33^{\prime} 27.1^{\prime \prime S} 105^{\circ} 15^{\prime} 09.0^{\prime \prime E}\right)$, Provinsi Lampung (Gambar 1). Teripang diambil dengan metode 


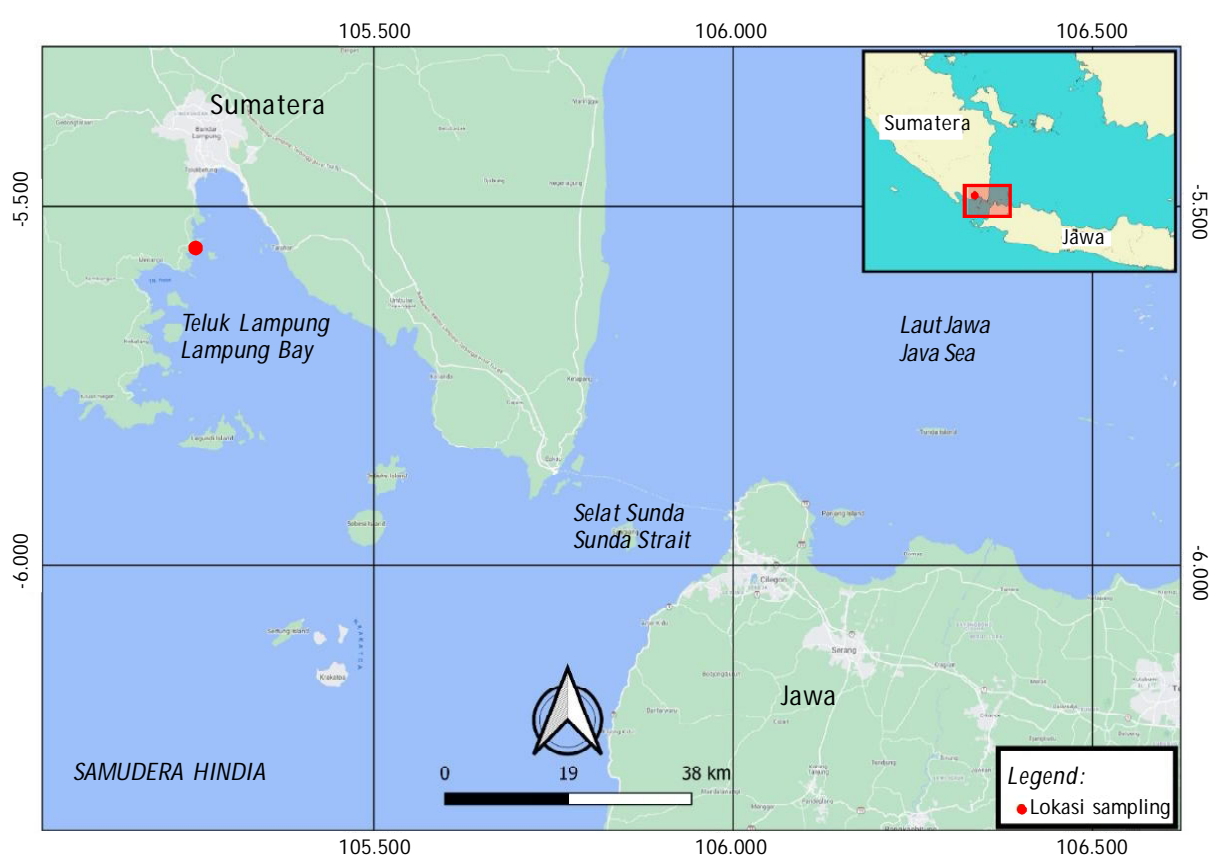

Gambar 1. Lokasi pengambilan sampel di perairan Lampung (5³3'27.1"S 105¹5'09.0"E), Provinsi Lampung, Indonesia.

Figure 1. Sampling location in Lampung waters $\left(5^{\circ} 33^{\prime} 27.1^{\prime \prime} S\right.$ $\left.105^{\circ} 15^{\prime} 09.0^{\prime \prime E}\right)$, Lampung Province, Indonesia.

jelajah pada saat surut dan dengan scuba diving. Sampel teripang yang diambil berjumlah delapan sampel, masing-masing spesies diambil satu individu (Gambar 2). Sampel kemudian dimasukan ke dalam plastik sampel yang berisi alkohol 90\% Untuk keperluan analisis DNA sampel teripang dimasukan ke dalam botol sampel dalam larutan ethanol $99 \%$

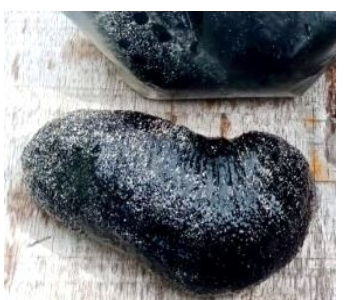

TRI991

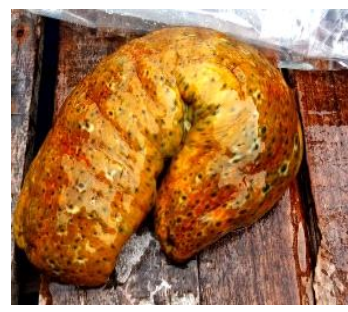

TRI995

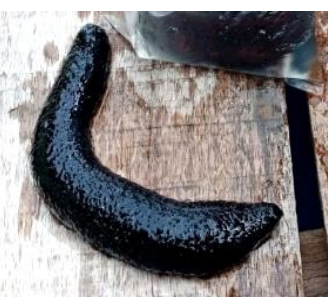

TRI992

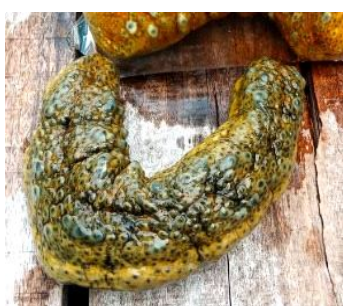

TRI996

\section{Ekstraksi DNA}

Ekstraksi DNA dilakukan dengan menempatkan irisan jaringan teripang ( $\pm 25 \mathrm{mg}$ ) ke dalam $1,5 \mathrm{~mL}$ tube microsentrifuges yang telah berisi $180 \mu \mathrm{L}$ larutan buffer ATL kemudian dihaluskan dengan menggunakan gunting bedah. Kemudian ditambahkan $20 \mu \mathrm{L}$ protein-

Gambar 2. Sampel teripang yang diperoleh selama penelitian.

Figure 2. Species of sea cucumber obtained during the field research. 
ase $\mathrm{K}$ dan di-vortex selama satu menit, serta diinkubasi selama semalam pada suhu $56^{\circ} \mathrm{C}$ di thermostat waterbath. Sampel yang telah diinkubasi di-vortex selama 15 detik dan ditambahkan $200 \mu \mathrm{L}$ buffer $\mathrm{AL}$ dan $200 \mu$ L ET-OH (96\%-100\%) lalu di-vortex selama dua menit. Selanjutnya sampel dipindahkan ke dalam DNA easy mini spin colomn yang sudah ditempatkan dalam 2 $\mathrm{mL}$ collection tube. Sampel di-sentrifugasi pada 8.000 rpm selama satu menit. Hasil sisa residu sentrifugasi dibuang dan DNA easy spin colomn dipindahkan dalam $2 \mathrm{~mL}$ collection tube yang baru. Selanjutnya dilakukan penambahan $500 \mu \mathrm{L}$ buffer AW1 dan di-sentrifugasi pada $8.000 \mathrm{rpm}$ selama satu menit. Spin colomn ditempatkan dalam $2 \mathrm{~mL}$ collection tube baru dan ditambahkan $500 \mu \mathrm{L}$ buffer AW2 kemudian disentrifugasi pada $14.000 \mathrm{rpm}$ selama tiga menit. Kemudian spin colomn dipindahkan ke dalam 1,5 mL microsentrifuge tubebaru. Eludasi DNA dilakukan dengan menambahkan $200 \mu \mathrm{L}$ buffer AE lalu inkubasi selama satu menit pada suhu ruang dan di-sentrifugasi pada 8.000 rpm selama satu menit. Konsentrasi dan kualitas ektrak DNA diukur pada nanophotometer IM PLEN dan disimpan pada freezer suhu $-80^{\circ} \mathrm{C}$.

\section{Analisis PCR}

Analisis PCR dilakukan dengan pembuatan larutan PCR yang terdiri 19,7 $\mu \mathrm{L}$ ddH2O; $3 \mu \mathrm{L}$ Taq buffer; $3 \mu \mathrm{L}$ $\mathrm{MgCl}_{2} ; 0,6 \mu \mathrm{L}$ dNTPmix; $0,5 \mu \mathrm{L} \mathrm{BSA}, 1 \mu \mathrm{L}$ primer forward dan reverse; $0,2 \mu \mathrm{L}$ Taq DNA; serta $1 \mu \mathrm{L}$ DNA template $( \pm 100 \mathrm{ng})$. Ruas gen COI genom mitokondria kemudian diamplifikasi menggunakan primer DNA barcoding primer forward COI ceF (5'ACTGCCCACGCCCTAGTAATGATATTTTTTATGGTNATGCC -3') dan primer reverse CO1 ceR (5'TCGTGTGTCTACGTCCATTCCTACTGTRAACATRTG 3') (Hoareau \& Boissin, 2010). Amplifikasi PCR dilakukan dengan mengatur suhu PCR step down antara lain; suhu pre-denaturation $95^{\circ} \mathrm{C}$ selama tiga menit, masing-masing 30 siklus dengan denaturasi pada suhu $94^{\circ} \mathrm{C}$ selama 45 detik, anneling pada suhu $60^{\circ} \mathrm{C}-55^{\circ} \mathrm{C}$ selama satu menit 10 detik; serta extention pada suhu $72^{\circ} \mathrm{C}$ selama satu menit 20 detik dan diakhiri dengan post extention pada suhu $72^{\circ} \mathrm{C}$ selama lima menit. Visualisasi hasil PCR dengan menggunakan gel eletroforesis $2 \%$ dan UV transluminator. Sampel hasil PCR yang teramplifikasi kemudian dikirim ke Macrogene untuk dilakukan sekuensing DNA.

\section{Analisis Data Hasil Sekuen}

Hasil sekuen diedit dan diurutkan dengan menggunakan program Geneious Prime, hasil aligment dicocokan dengan program Basic Local Assignment Search Tool (BLAST) dan validasi spesies dengan tingkat kesamaan 99\%100\% Konstruksi pohon filogenetik dilakukan pada program MEGA $X$ dengan menambahkan sekuen dari GenBank dengan kode antara lain JN207617.1, LC217310.1, KX874353.1, KY986418.1 dengan tingkat kesamaan tertinggi. Analisis filogenetik menggunakan metode neighbor joining ( $\mathrm{NJ}$ ) dengan model Kimura-2 parameter dengan uji pada 1.000x bootstrap (Tamura et al., 2011).

\section{HASIL DAN BAHASAN}

\section{Budidaya Teripang}

Budidaya teripang saat ini masih mengandalkan bibit dari alam, kemudian diperbesarkan dalam kolam perbesaran (karamba tancap). Di Indonesia jenis teripang yang dibudidayakan dan dimanfaatkan antara lain teripang pasir (Holothuria scabra), teripang perut hitam (Holothuria atra, teripang susuan (Holothuria edulis), dan teripang nanas (Thelenota ananas). Pengambilan bibit di alam oleh para nelayan umumnya dengan ukuran teripang 40-60 g/ekor. Penebaran bibit umumnya dilakukan pada pagi atau sore hari dengan padat tebar 3-5 ekor $/ \mathrm{m}^{2}$. Penambahan pakan umumnya dilakukan seminggu sekali dapat berupa pellet maupun sisa makanan. Masa pemeliharan berkisar 4-6 bulan tergantung ukuran benih saat ditebar. Teripang dipanen dengan ukuran 400-600 g/ekor pada saat surut terendah (Tangko, 2009). Budidaya teripang dilakukan pada jenis teripang yang sama dalam satu karamba sehingga penentuan jenis teripang yang tepat dalam budidaya teripang harus dilakukan agar budidaya teripang memperoleh hasil yang maksimal.

\section{Identifikasi Sampel}

Dari delapan sampel teripang hanya empat sampel yang menghasilkan konsentrasi dan kualitas DNA yang baik (Tabel 1 ).

Hasil konsentrasi DNA berkisar antara 12-161,75 $\mathrm{ng} / \mu \mathrm{L}$. Sekuen DNA Cytochorme Oxydase Subunit I (COI) yang dihasilkan adalah sepanjang $525 \mathrm{bp}$. Berdasarkan BLAST yang dilakukan menggunakan data sekuen gene bank tidak ditemukan adanya insertion dan diletion. Berdasarkan hasil analisis dengan menggunakan BLAST sampel TR1992 teridentifikasi dengan Holothuria leucospilota, TR1993 teridentifikasi dengan $H$. atra, TR1997 teridentifikasi dengan Stichopus vastus dan TR 1998 teridentifikasi dengan S. horrens (Tabel 2).

Semakin tinggi nilai identity antar spesies menunjukkan kesamaan spesies yang semakin tinggi. Nilai identity yang lebih besar dari 95\%dan mendekati $100 \%$ serta nilai $\mathrm{E}=0$ menunjukkan tingkat kesamaan spesies yang tinggi. (Madduppa et al., 2017). Penelitian ini menunjukkan nilai identity berkisar $99 \%$ $100 \%$ dengan demikian hasil BLAST yang diperoleh 
Tabel 1. Konsentrasi DNA teripang

Table 1. DNA concentration of sea cucumber

\begin{tabular}{ccc}
\hline $\begin{array}{c}\text { Kode sampel } \\
\text { Sample code }\end{array}$ & $\begin{array}{c}\text { Kode ekstrak DNA } \\
\text { DNA extract code }\end{array}$ & $\begin{array}{c}\text { Konsentrasi DNA } \\
\text { DNA concentration }(\mathbf{n g} / \mu \mathrm{L})\end{array}$ \\
\hline TR1991 & TC91 & - \\
TR1992 & TC92 & 12.5 \\
TR1993 & TC93 & 41.5 \\
TR1994 & TC94 & 2.4 \\
TR1995 & TC95 & - \\
TR1996 & TC96 & - \\
TR1997 & TC97 & 22.05 \\
TR1998 & TC98 & 421.45 \\
\hline
\end{tabular}

Tabel 2. Hasil identifikasi melalui program BLAST I

Table 2. Identification results through BLAST program

\begin{tabular}{cccccc}
\hline $\begin{array}{c}\text { Kode sampel } \\
\text { Sample code }\end{array}$ & $\begin{array}{c}\text { Kode DNA } \\
\text { DNA code }\end{array}$ & $\begin{array}{c}\text { identifikasi BLAST } \\
\text { BLAST identified }\end{array}$ & $\begin{array}{c}\text { Identifikasi } \\
\text { Identity } \text { \% }\end{array}$ & $\begin{array}{c}\text { Nilai E } \\
\text { E value }\end{array}$ & $\begin{array}{c}\text { Nomor aksesi } \\
\text { Accesion number }\end{array}$ \\
\hline TR1992 & TC92 & Holothuria leucospilota & 99.67 & 0 & JN207617.1 \\
TR1993 & TC93 & Holothuria atra & 100 & 0 & LC217310.1 \\
TR1997 & TC97 & Stichopus vastus & 100 & 0 & KX874353.1 \\
TR1998 & TC98 & Stichopus horrens & 99.83 & 0 & KY986418.1 \\
\hline
\end{tabular}

pada penelitian ini menunjukkan tingkat validasi kesamaan spesies yang tinggi.

Setyastuti et al. (2019) menyatakan $\mathrm{H}$. atra ditemukan di 23 lokasi di Indonesia antara lain di Sabang, Nias, Mentawai, Batam, Bintan, Lingga, Belitung, Lampung, Karimunjawa, Jawa Timur, Sumbawa, Derawan, Makassar, Selayar, Sumba, Kendari, Wakatobi, Buton, Ternate, Seram, Ambon, Raja Ampat, dan Kaimana. H. leucospilota ditemukan di 14 lokasi antara lain di Batam, Bintan, Belitung, Karimunjawa, Jawa Timur, Lombok Barat, Sumbawa, Makassar, Sumba, Kendari, Buton, Seram, Ambon, dan Biak. S. horrens ditemukan di lima lokasi yaitu Karimunjawa, Jawa Timur, Derawan, Selayar, Seram. Sementara itu, S. vastus ditemukan di delapan lokasi di Indonesia yaitu Lampung, Karimunjawa, Jawa Timur, Derawan, Selayar, Ternate, Seram, dan Kaimana. Penelitian ini menunjukan distribusi $H$. leucospilota dan S. horrens juga terdapat di perairan Lampung. Namun demikian, dilaporkan bahwa Wibowo et al. (2019) telah melakukan penelitian pada $\mathrm{H}$. leucospilota yang berasal dari perairan Lampung. Sedangkan, Rasyid et al. (2018) melakukan analisis pada S. horrens yang berasal dari perairan Teluk Rantai, Lampung. Dengan demikian keberadaan kedua spesies tersebut di Lampung dapat dikonfirmasi dengan hasil penelitian yang dilakukan.

\section{Pohon Filogenetik}

Jarak genetik antar spesies teripang disajikan pada Tabel 3. Penelitian ini menunjukkan jarak genetik berkisar antara 0,0668-0,3012 dengan jarak genetik terendah antara Stichopus vastus dan S. horrens yaitu 0,0668 dan tertinggi sebesar 0,3012 yaitu antara Holothuria leucospilota dan S.vastus. Perbedaan jarak genetik dipengaruhi oleh beberapa faktor antara lain genetic drift dan seleksi alam (Freeland, 2012). Semakin rendah jarak genetik antar spesies menunjukkan semakin sedikit perbedaan pasangan basa antar spesies yang diikuti dengan semakin tinggi persamaan morfologinya. Penelitian ini menunjukkan genus Stichopus memiliki jarak genetik terendah, hal yang sama dilaporkan oleh Madduppa et al. (2017) pada jenis-jenis teripang di Kepulauan Seribu.

Hewan invertebrata umumnya memiliki kesamaan morfologi yang tinggi antar spesies (cryptic), sehingga identifikasi molekuler dapat digunakan untuk memvalidasi spesies kriptik. Menurut Patantis et al. (2019), secara molekuler, jenis-jenis teripang yang ada di perdagangkan di Indonesia adalah Acaudina sp., Actinopyga echinites, A. lecanora, A. miliaris, Bohadschia argus, B. marmorata, B. ocellata, B. vitiensis, Holothuria sp., H. atra, H. coluber, H. edulis, $H$. excellens, $H$. fuscocinerea, $H$. fuscogilva, $H$. 
Tabel 3. Jarak genetik antar spesies teripang yang teridentifikasi dalam penelitian Table 3. Genetic distance between spesies of sea cucumber identified in the study

\begin{tabular}{lcccc}
\hline \multicolumn{1}{c}{ Spesies (Species) } & Stichopus horrens & Stichopus vastus & Holothuria atra & Holothuria \\
\hline Stichopus horrens & & & & \\
Stichopus vastus & 0.0668 & & & \\
Holothuria atra & 0.256 & 0.2597 & \\
Holothuria leucospilota & 0.2855 & 0.3012 & 0.2053 & \\
\hline
\end{tabular}

fuscopunctata, H. scabra, Pearsonothuria graeffei, Phyrella sp., Stichopus herrmanni, S. horrens, dan S. monotuberculatus. Penelitian tersebut juga menyebutkan rendahnya jarak genetik antar genus Stichopus menyebabkan seringnya terjadi kesalahan identifikasi pada genus Stichopus.

Rekonstruksi pohon filogenetik spesies-spesies yang ada dibandingkan dengan data GenBank ditampilkan pada Gambar 3. Pohon filogenetik menunjukkan bahwa pengelompokan spesies-spesies terjadi karena kesamaan genetik terkait hubungan kekerabatan. Genus Holothuria bercabang membentuk dua clade. Hal ini kemungkinan disebabkan tingginya variabilitas $\mathrm{COI}$ pada genus Holothuria. Holothuria terdiri atas 18 subgenera yang selanjutnya dibagi menjadi 160 spesies, sedangkan genus lainnya belum dibagi menjadi subgenera (Honey et al., 2012). Genus Stichopus memiliki clade dengan nilai bootstrap yang tinggi yang menunjukkan hubungan kekerabatan yang dekat.

Identifikasi spesies secara molekular dapat mengungkap keanekeragaman spesies secara cepat dan akurat. Identifikasi yang tepat dapat memberikan data yang penting terkait distribusi dan jumlah populasi teripang di alam sehingga pengelolaan teripang baik secara budidaya maupun pengambilan langsung di alam dapat berkelanjutan. Penggunaan DNA barcoding dalam penentuan identifikasi spesies teripang dalam penelitian ini dapat dijadikan referensi dalam pengembangan budidaya dan konservasi teripang di Indonesia khususnya di perairan Lampung, sehingga proses budidaya dapat tepat sasaran.

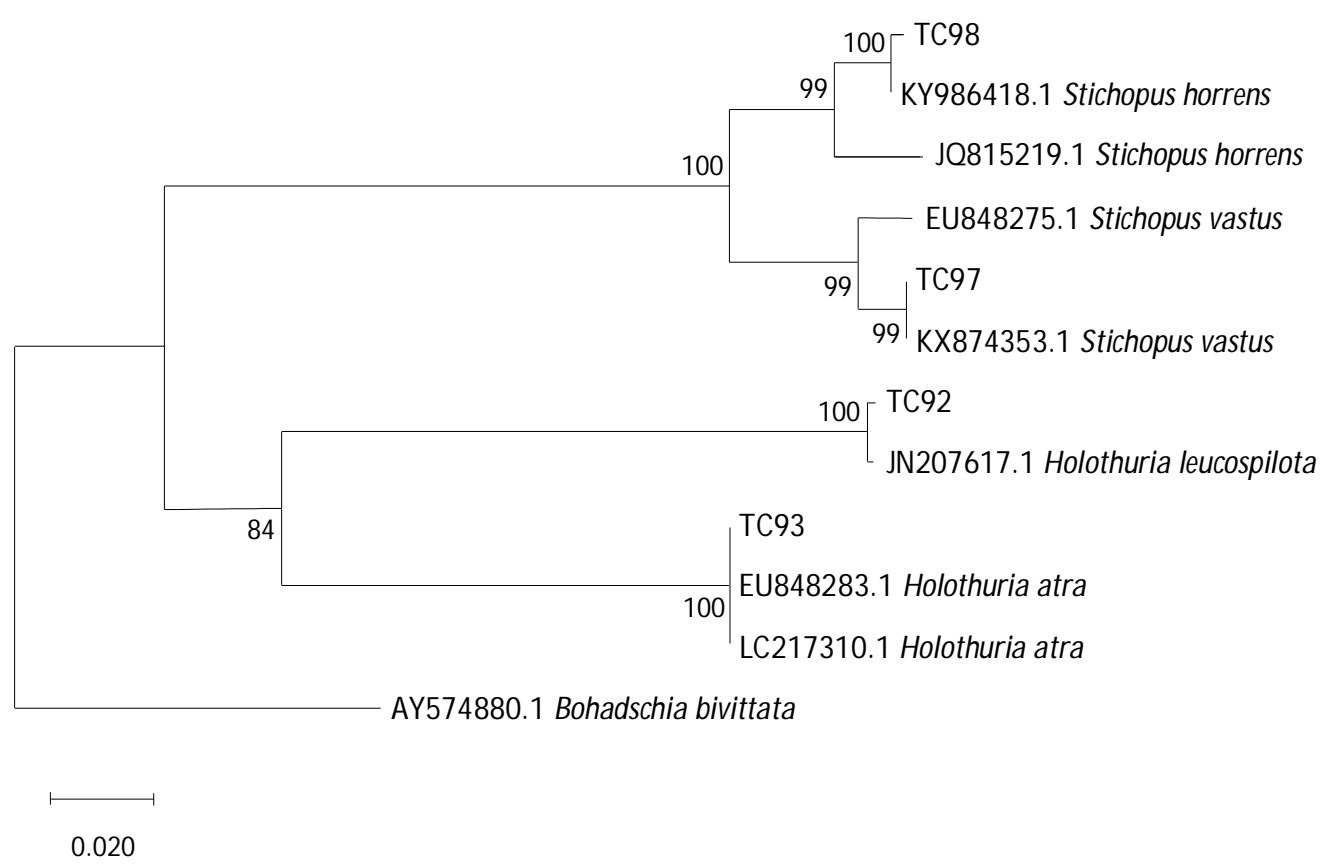

Gambar 3. Pohon filogenetik teripang berdasarkan sekuen DNA COI gen menggunakan metode neighbor joining (NJ) dengan model Kimura-2 parameter, bootstrap 1.000 replikasi.

Figure 3. Phylogenetic tree of sea cucumbers based on DNA COI gen sequen using the neighbor joining (NJ) method with a 2-parameter Kimura model, bootstrap 1,000 replications. 


\section{KESIMPULAN}

Identifikasi spesies yang tepat menjadi kunci utama dalam upaya pembudidayaan dan konservasi teripang yang tepat sasaran dan berkelanjutan. Secara morfologis terdapat delapan jenis teripang yang diperoleh dari perairan Lampung. Empat di antaranya teridentifikasi sebagai Holothuria leucospilota, H. atra, Stichopus vastus, dan S. horrens. Stichopus vastus dan S. horrens memiliki jarak genetik terendah dan nilai bootstrap yang tinggi. Pohon filogenetik menunjukkan pengelompokkan spesies-spesies berdasarkan genus yang berbeda. Teripang jenis Stichopus sp. memiliki kesamaan morfologi yang tinggi sehingga kesalahan identifikasi sering terjadi. DNA barcoding dapat mengidentifikasi teripang secara cepat dan akurat sehingga pengelolaan teripang baik secara budidaya maupun pengambilan langsung di alam dapat berkelanjutan. Keanekaragaman genetik dan studi populasi teripang perlu dilakukan sehingga upaya konservasi teripang dapat optimal.

\section{UCAPAN TERIMA KASIH}

Ucapan terima kasih disampaikan kepada Kepala Pusat Penelitian Oseanografi, Lembaga IImu Pengetahuan Indonesia (LIPI) yang mengizinkan penelitian ini berlangsung. Ucapan terima kasih disampaikan kepada Aji Nugroho yang membantu dal am pengambilan sampel. Penelitian ini dibiayai oleh Pusat Penelitian Oseanografi LIPI melalui dana COREMAP-CTI tahun 2019.

\section{DAFTAR ACUAN}

Briski, E., Cristescu, E., Bailey, S., \& Maclsaac, H. (2011). Use of DNA barcoding to detect invertebrate invasive species from diapausing eggs. Biological Invasions, 13(6), 1325-1340.

Convention on International Trade In Endangered Species of Wild Fauna and Flora [CITES]. (2020). Appendices I, II and III. Geneva: UN Environment Programme (UNEP), $74 \mathrm{pp}$.

Freeland, J.R., Kirk, H., \& Petersen. S. (2012). Genetic analysis of multiple populations in molecular ecology. $2^{\text {nd }}$ edition. New York: John Wiley and Sons.

Hebert, P.D.N., Cywinska, A., Ball, S., \& deWaard, J.R. (2003). Biological identifications through DNA barcodes. Proceeding Biological Sciences Royal Society London B, 270, 313-21.

Hoareau, T.B. \& Boissin, E. (2010). DNA barcoding design of phylum-speciûc hybrid primers for DNA barcoding: addressing the need for efûcient COI ampliûcation in The Echinodermata. Molecular Ecology Resources, 10, 960-967.
Honey, E.M., Figueras, L.A., \& MaríN, S.F.A. (2012). Molecular phylogeny of the subgenus Holothuria (Selenkothuria) Deichmann, 1958 (Holothuroidea: Aspidochirotida). Zool. J. Linn. Soc., 165(1), 109-120.

Madduppa, H., Taurusman, Am.A., Subhan, B., Anggraini, N.P., Fadillah, R., \& Tarman, K. (2017). Short communication: DNA barcoding reveals vulnerable and not evaluated species of sea cucumbers (Holothuroidea and Stichopodidae) from Kepulauan Seribu Reefs, Indonesia. Biodiversitas, 18(3), 893-898.

Patantis, G., Dewi, A.S., Fawzya, Y.N., \& Nursid, M. (2019). Identification of Beche-de-mers from Indonesia by molecular approach. Biodiversitas, 20(2), 537-543.

Rasyid, A., Wahyuningsih, T., \& Ardiansyah, A. (2018). Profil metabolit sekunder, aktivitas antibakteri dan komposisi senyawa yang terkandung dalam ekstrak metanol teripang Stichopus horrens. Jurnal Ilmu dan Teknologi Kelautan Tropis, 10(2), 333-340.

Setyastuti, A., Wirawati, I., Permadi, S., \& Vimono, I.B., (2019). Teripang Indonesia: Jenis, sebaran, dan status nilai ekonomi. Bogor: PT. Media Sains Nasional, $75 \mathrm{hlm}$.

Tangko, A.M. (2009). Present status produksi dan budidaya teripang di Sulawesi Selatan. Media Akuakultur, 4(1), 32-39.

Tamura, K., Peterson, D., Peterson, N., Stecher, G., Nei, M., \& Kumar, S. (2011). MEGA5: molecular evolutionary genetics analysis using maximum likelihood, evolutionary distance, and maximum parsimony methods. Molecular Biology and Evolution, 28, 2731-2739.

Trivedi, S., Aloufi, A.A., Ansari, A.A., \& Ghosh, S.K. (2016). Review: Role of DNA barcoding in marine biodiversity assessment and conservation: An update. Saudi Journal of Biological Sciences, 23, 161-171.

Wirawati, I., Setyastuti, A., \& Purwati, P. (2019). Timun Laut dari Perairan Dangkal Indonesia. Jakarta: Media Sains Nasional, $93 \mathrm{hlm}$.

Wibowo, T.J., Murniasih, T., Kellermann, M.Y., Versluis, D., Putra, M.Y., Praditya, D.F., Mohr, K.I., Wink, J., Engelmann, M., Steinmann, E., \& Schupp, P.J. (2019). Biotechnological potential of bacteria isolated from the sea cucumber Holothuria leucospilota and Stichopus vastus from Lampung, Indonesia. Marine. Drugs, 17(635), 1-25.

Zein, M.S.A. \& Prawiradilaga, D.M. (2013). DNA barcode fauna Indonesia. Jakarta: Prenada Media, $260 \mathrm{hlm}$. 